\title{
PENYULUHAN ORANG TUA DAN BIMBINGAN BELAJAR ANAK DI JAKARTA BARAT
}

\author{
Wiyun Philipus Tangkin ${ }^{1}$, Juniriang Zendrato ${ }^{2}$ \\ ${ }^{1}$ Universitas Pelita Harapan \\ ${ }^{2}$ Universitas Pelita Harapan
}

wiyun.tangkin@uph.edu, juniriang.zendrato@uph.edu

\begin{abstract}
Abstrak
Minimnya pengetahuan orang tua mengenai kedisiplinan memengaruhi peran orang tua dalam mendidik anakanaknya, sehingga membentuk mereka yang kurang disiplin. Hal inilah yang melatarbelakangi Pengabdian Kepada Masyarakat (PKM) dilaksanakan dalam bentuk penyuluhan orang tua dan bimbingan belajar bagi anak-anak di Kelurahan Wijaya Kusuma Jakarta Barat. Penyuluhan ini bertujuan agar orang tua dapat lebih merefleksikan kembali tentang peran mereka sebagai pendidik utama dalam kehidupan anak-anaknya. Bimbingan belajar yang dilakukan dilatarbelakangi oleh sikap anak-anak yang pasif dan masih takut dalam mengekspresikan diri baik secara tertulis maupun lisan. Pada pelaksanaan bimbingan belajar ini, anak-anak diarahkan untuk lebih mengenal tentang siapa diri mereka, keluarga mereka, cita-cita, dan harapan mereka. Anak-anak dilatih untuk dapat mengekspresikan dan menyampaikan gambaran tentang dirinya, keluarganya, harapan, dan cita-cita dalam bentuk lisan maupun tulisan. Metode yang digunakan dalam bimbingan belajar ini bervariasi seperti permainan, ceramah interaktif, kerja kelompok, maupun tugas mandiri. Hasil pengamatan selama pembelajaran adalah anak-anak terlihat lebih baik dalam hal karakter yaitu lebih disiplin dan menunjukkan sikap mau bekerja sama dengan temanteman mereka. Dari hasil evaluasi pelaksanaan penyuluhan, orang tua merasa bahwa penyuluhan ini penting dan berguna bagi mereka di dalam mendidik anak-anak mereka di rumah.
\end{abstract}

Kata kunci: penyuluhan, bimbingan belajar, marjinasi

\section{PENDAHULUAN}

Kegiatan PKM ini merupakan keberlanjutan dari Bimbingan Belajar yang diadakan pada tahun akademik 2015/2016 dengan judul "Kursus Bahasa Indonesia dan Bahasa Inggris di kelurahan Wijaya Kusuma Jakarta Barat" dan tahun akademik 2016/2017 dengan judul "Kursus Calistung, Matematika, dan Bahasa Inggris di Kelurahan Wijaya Kusuma Jakarta Barat". Penambahan mata pelajaran dalam bidang studi Calistung (baca, tulis, dan hitung) dan Matematika, karena melihat kebutuhan dari anak-anak yang berada di kelurahan tersebut. Melihat animo belajar dari masyarakat sekitar yang semakin hari semakin meningkat, maka kami memutuskan untuk melanjutkan program ini dengan tetap bekerja sama dengan SMP Taqwa yang berada di lingkungan tersebut untuk meminjamkan ruang kelas yang dipakai saat pelaksanaan kegiatan ini.

Kegiatan PKM berupa Bimbingan Belajar ini dilatar belakangi oleh kondisi anak-anak yang kurang menyadari akan pentingnya penggunaan bahasa Indonesia yang baik dan benar sehingga tingkat kemampuan membaca, mendengar, dan menulis dalam bahasa Indonesia juga rendah. Bukan hanya itu saja, terlihat juga sikap siswa yang pasif dan masih takut dalam mengekspresikan diri baik secara tertulis maupun lisan. Tidak percaya diri dalam penggunaan bahasa Inggris juga melatarbelakangi diadakannya PKM ini.

Menurut Vygotsky (1962), anak-anak menggunakan bahasa bukan hanya untuk

$$
\text { Pendidikan }
$$


komunikasi sosial, tetapi untuk merencanakan dan memonitor perilaku mereka dengan caranya sendiri. Jadi betapa pentingnya belajar bahasa, karena bahasa adalah bentuk komunikasi, baik dalam lisan, tertulis, tanda, ataupun simbol. Bahasa dipakai setiap hari, bahkan tidak mengenal waktu dan tempat. Dengan bahasa manusia bisa berhubungan dengan sesamanya. Sependapat dengan pernyataan seblumnya, Khairani (2018) juga menjelaskan bahwa bahasa merupakan alat untuk mengungkapkan perasaan dan mengekspresikan diri. Melalui bahasa, kita dapat mengungkapkan secara terbuka apa yang tersirat di dalam hati maupun pikiran.

Manfaat mempelajari bahasa Indonesia, yaitu dapat meningkatkan pengetahuan dan keterampilan dalam melestarikan dan mengembangkan budaya, mengembangkan ilmu pengetahuan, teknologi, dan seni, berkomunikasi dengan bahasa Indonesia yang baik dan benar, baik secara lisan maupun tulisan, dan membantu mengemukakan pendapat yang baik dan sopan. Hal ini sejalan dengan yang dikatakan oleh Nurfadila bahwa bahasa merupakan alat utama untuk mengungkapkan pikiran dan perasaan seseorang. Pembelajaran bahasa Indonesia di lingkup dunia akademik khususnya dan pada umumnya memiliki tujuan mendidik anak didik dan masyarakat agar dapat berkomunikasi dengan menggunakan bahasa Indonesia secara efektif dan benar sesuai dengan etika dan kesopanan, supaya anak didik dapat meningkatkan kemampuannya dan bangga menggunakan bahasa Indonesia sebagai bahasa persatuan bangsa Indonesia. Menurut Sabri belajar bahasa Indonesia bukan hanya sekedar berkomunikasi melainkan, belajar mencintai bangsa dan budaya Indonesia. Selain itu bahasa adalah pintu untuk mengetahui banyak pengetahuan, mengetaui lingkungannya, bahkan bahkan mengenali dirinya.

Dalam PKM ini juga anak-anak juga diajarkan untuk bisa bekerjasama dengan temantemannya. Manusia diciptakan sebagai makhluk sosial, dimana dalam hidupnya berelasi dengan manusia lainnya. Dalam menjalani hidup sebagai manusia, maka diperlukan kemampuan untuk dapat bekerja sama. Berelasi merupakan kebutuhan hidup manusia, oleh karena itu sejak usia dini manusia perlu diajarkan bagaimana berelasi dengan dengan benar terhadap sesamanya. Menurut Santosa (2004) dalam Triyanti \& Saparahayuningsih (2016), bekerja sama adalah suatu bentuk interaksi sosial ketika tujuan kelompok anggota yang satu berkaitan dengan tujuan anggota kelompok yang lain. Sehingga seluruh anggota kelompok dapat mencapai tujuannya. Dengan kata lain, bekerja sama dapat dilakukan ketika yang melakukan memiliki tujuan yang sama. Sifat khusus dan kebutuhan seorang anak adalah bersukaria dan bermain. Bermain adalah bentuk kesenangan dan sumber kesenangan bagi pesertanya, oleh karena itu bermain dapat dijadikan metode untuk anak belajar, dimana di dalamnya anak dapat belajar bekerjasama (Mursi, 2013). Menurut Bestani, dkk. (2015), bekerja sama juga membantu anak untuk memiliki sikap toleransi. Sikap individualisme yang sering muncul pada anak-anak akan berdampak negatif. Dampaknya adalah membuat anak tidak dapat berelasi dengan orang lain, selain itu anak sulit mengembangkan dirinya dengan kehidupan di luar dirinya, karena merasa tidak membutuhkan orang lain. Oleh karena itu dalam bimbingan belajar ini anak juga diajar bekerjasama dengan teman-temannya melalui permainan.

Rosita \& Leonard (2013), berpendapat bahwa anak yang dapat bekerjasama dengan temantemannya, memiliki kepercayaan diri, bahkan kepekaan dan empati dalam berelasi dengan lingkungannya. Dalam bekerja sama, anak belajar memahami orang lain, menerima kelebihan, bahkan kekurangan orang lain, belajar mengenali dirinya yang menyangkut kekuatan serta kelemahannya, belajar bersukacita bersama, bahkan berdukacita bersama.

Selain bimbingan belajar, kami juga mengadakan penyuluhan kepada orang tua siswa. Adapun hal yang melatarbelakangi diadakannya penyuluhan ini adalah karena melihat minimnya pengetahuan orang tua sebagai pendidik utama dalam mendidik anak-anaknya. Dampaknya akan mempengaruhi orang tua dalam mengajar dan mendidik anak-anaknya setiap hari. Serta mempengaruhi orang tua dalam mendisiplinkan anak-anaknya. Minimnya pengetahuan orang tua siswa tersebut terlihat dari anak-anak yang kurang disiplin, pasif, dan terkesan takut mengekspresikan diri baik secara tertulis maupun lisan.

Anak-anak merupakan manusia kecil yang akan beranjak dewasa, dan kemudian hari akan menjalankan perannya juga sebagai orang tua bagi

$$
\text { Pendidikan }
$$


generasi berikutnya. Demikianlah manusia menjalankan hidupnya melalui generasi ke generasi. Namun jika tidak disadari akan pentingnya pendidikan dalam keluarga, maka pengaruhnya dan dampaknya akan semakin besar bahkan dari ke generasi ke generasi. Menurut Megawati, Asriati, dan Rustiyarso (2017), peranan orang tua sebagai pendidik utama dan pertama bagi anak, memberikan peranan untuk dapat memberikan pendidikan awal sebagai bekal pengalaman untuk anak-anaknya. Peranan orang tua ini sangat penting bagi pendidikan anak-anak karena orang tua memberikan pengaruh yang signifikan terhadap perilaku anak, sebab seorang anak akan meniru apa yang akan dilakukan oleh orang tuanya. Orang tua merupakan role model bagi anak. Oleh karena itu, orang tua tidak boleh menganggap bahwa pendidikan di dalam keluarga itu tidak penting, karena dasar yang utama yang harus orang tua berikan kepada anak adalah pendidikan di dalam keluarga.

Hal ini sejalan dengan yang dikatakan oleh Brummelen (2006 Hal. 12) bahwa pendidikan di rumah bersifat informal melalui interaksi sehari-hari seperti diskusi, bermain bersama, membagikan pekerjaan rumah tangga, berjalan-jalan, menonton bersama, dan lain sebagainya. Oleh karena itu tanggung jawab pendidikan dasar anak-anak tetap berpulang pada orang tua. Rumah adalah tempat menanamkan perilaku dasar terhadap Tuhan sebagai pencipta-Nya, orang lain, diri sendiri, otoritas, dan pelajaran. Dengan demikian orang tua harus memiliki pengaruh besar terhadap sekolah dan bagaimana anak-anak mereka mengalaminya. Sekolah adalah komunitas yang hanya akan berkembang bila orang tua memiliki peranan yang berarti dalam pelaksanaannya.

Salah satu bentuk pendidikan anak di rumah melalui orang tua adalah mengenai kedisiplinan. Minimnya pengetahuan orang tua mengenai kedisiplinan akan berdampak pada perilaku anakanaknya. Orang tua di dalam keluarga bertanggung jawab untuk memperhatikan tumbuh kembang anak, mengawasi perkembangan anak, serta mengajarkan nilai-nilai agama, akhlak, budaya, dan sosial bagi anak. Menurut Fitri A., dkk. Disiplin merupakan salah satu aspek yang sangat penting yang harus tertanam dalam diri anak sejak dini. Dengan disiplin anak dapat memperoleh suatu bantasan untuk memperbaiki tingkah lakunya yang salah. Disiplin dapat mendorong, membimbing, dan membantu anak memperoleh perasaan puas, setia, patuh, serta mengajarkan anak berpikir secara teratur. Karena melaui disiplin, anak-anak dapat bejar berperilaku yang dapat diterima oleh lingkungan sosialnya serta bertanggung jawab terhadap perilaku anak serta tindakan yang sesuai dengan karakteristik anak. Suprapto (2014) berpendapat bahwa anak yang memiliki displin tidak lepas dari peran orang tua dalam mengontrol dan mengingatkan apabila anak mulai malas. Bimbingan dari orang tua yang mendidik anak dengan tegas dan mengupayakan terpenuhinya lingkungan yang baik, membuat anak menangkap apa yang diupayakan orang tuanya. Pengarus berupa motivasi dan dorongan sedikit saja, maka anak sudah bisa bangkit dan kembali semangat lagi, asalkan orang tua memberikan dorongan yang positif saat mendisiplinkan anak.

Penanaman disiplin bahkan harus dimulai dari usia pra sekolah. Penanaman disiplin pada anak bukan produk yang sekali jadi, melainkan harus melalui proses pembiasaan yang terus menerus. Membutuhkan waktu yang lama, butuh kesabaran dan komitmen dari orang tua untuk terus menerus melatih anak-anaknya, bahkan dengan berulangulang. Orang tua bukan saja sebagai pelatih dan pembimbing, namun orang tua harus menjadi pelaku. Misalnya mendisiplinkan anak setiap malam jam 20:00-21:00 untuk membaca buku, maka orang tua juga harus komitmen melakukan hal tersebut bahkan rela tidak melakukan kegemarannya seperti menonton tv atau memegang gadget. Perilaku atau tindakan akan sangat berpengaruh ketimbang katakata bagi anak-anak. Menurut Guntur, dkk. (2018), beberapa hal yang penting untuk diperhatikan oleh odang tua dalam mendisiplinkan anak-anaknya adalah 1) Orang tua harus tegas. Ketegasan yang dimaksudkan adalah berbeda dengan galak. Tegas berarti berpendirian dengan alasan yang logis sedangkan galak adalah emosi dengan tidak memiliki dasar yang logis. 2) Orang tua perlu memberikan apresiasi berupa reward untuk memotivasi anak. Pemberian motivasi juga harus yang wajar. Tidak harus berupa barang, namun berupa pujian dan pelukan juga bisa. 3) Jika memberikan hukuman, maka harus disesuaikan dengan kondisi anak, dan pelanggarannya. 4) Berikan ruang diskusi kepada anak untuk menyatakan pendapatnya. Hal ini sangat penting dilakukan, karena dengan ini maka orang tua

$$
\text { Pendidikan }
$$


dapat memahami kondisi anak, begitu juga anak memahami orang tua. 5) Hindari hukuman fisik. Hal ini penting untuk diperhatikan oleh orang tua, karena sering sekali orang tua mengikuti emosinya sehingga ketika marah oleh pelanggaran anak, maka yang terlintas adalah langsung menghukum fisik anak. Dampak yang akan ditimbulkan sangat negatif kepada anak, karena anak bisa berontak atau patuh, namun karena takut bukan karena memahami pelanggarannya. 6) Orang tua harus menjadi teladan. Hal ini harus menjadi fokus utama, karena sering sekali orang tua hanya menuntut anak, tanpa memahami bahwa kewajiban orang tua adalah menjadi role model atau teladan dalam kehidupan anak-anaknya. Jika orang tua menghendaki anaknya disiplin, maka harus dimulai dari orang tua untuk disiplin.

Berdasarkan uraian di atas, maka diadakanlah PKM ini dalam bentuk bimbingan belajar dan penyuluhan kepada orang tua.

\section{METODE}

Berikut adalah metode pelaksanaan PKM:

1) Ketua PKM menyusun silabus pelajaran berdasarkan analisis kebutuhan masyarakat; 2) Ketua PKM mem-briefing seluruh mahasiswa pengajar mengenai tujuan kegiatan dan silabus; 3) Para mahasiswa menyusun materi dan Lembar Kerja Siswa (LKS) berdasarkan silabus yang telah disusun dan langkah-langkah mengajar; 4) Ketua PKM mengkaji ulang materi dan LKS yang telah disusun dan langkah-langkah mengajar; 5) Ketua PKM menyusun buku panduan mengajar bagi guru dan buku siswa; 6) Ketua PKM membagi siswa dalam 3 kelas yaitu pra-TK dan TK, Kelas SD 1-3, dan kelas SD 4-6; 7) Ketua PKM menunjuk mahasiswa sebagai guru untuk tiap kelasnya; 8) Ketua PKM mengobservasi dan mendampingi para mahasiswa setiap mengajar dan memberikan umpan balik; 9) Para mahasiswa melakukan evaluasi pengajaran secara bersama setiap akhir kelas; 10) Para mahasiswa meminta evaluasi kegiatan dari siswa dan orang tua untuk keseluruhan bimbingan belajar yang sudah terlaksana; 11) Para mahasiswa guru menulis rapor untuk performansi belajar setiap siswa dalam bentuk narasi yang dibagikan di akhir bimbingan belajar; 12) Saran, evaluasi, dan refleksi guru, refleksi orang tua, dan refleksi siswa, akan dijadikan masukan untuk memperbaiki program bimbingan belajar yang akan dilaksanakan semester berikutnya.

\section{HASIL DAN PEMBAHASAN}

\section{Pelaksanaan PKM}

Berikut adalah skema pelaksanaan PKM yang telah dilaksanakan:

\begin{tabular}{|c|c|c|c|c|}
\hline No & Kegiatan & Tanggal & Tema & Peserta \\
\hline 1 & $\begin{array}{l}\text { Penyuluhan } \\
\text { orang tua }\end{array}$ & 10 Feb 2018 & $\begin{array}{l}\text { Apakah aku } \\
\text { mencintai } \\
\text { anakku? }\end{array}$ & 15 \\
\hline \multirow[t]{4}{*}{2} & \multirow{4}{*}{$\begin{array}{l}\text { Bimbingan } \\
\text { Belajar } \\
\text { Bahasa } \\
\text { Indonesia }\end{array}$} & 17 Mar 2018 & Diriku & 37 \\
\hline & & 24 Mar 2018 & Cita-citaku & 46 \\
\hline & & 7 Apr 2018 & Keluargaku & 38 \\
\hline & & 21 Apr 2018 & Ceritaku & 38 \\
\hline \multirow[t]{4}{*}{3} & \multirow{4}{*}{$\begin{array}{l}\text { Bimbingan } \\
\text { Belajar } \\
\text { Bahasa } \\
\text { Inggris }\end{array}$} & 28 Apr 2018 & Nama buah & 24 \\
\hline & & 5 Mei 2018 & $\begin{array}{l}\text { Barang-barang } \\
\text { di rumah }\end{array}$ & 28 \\
\hline & & 12 Mei 2018 & Alat transportasi & 36 \\
\hline & & 19 Mei 2018 & Review & 35 \\
\hline
\end{tabular}

Pelaksanaan PKM ini diadakan sebanyak 9 kali pertemuan, dari bulan Februari hingga Mei 2018. Bekerja sama dengan SMP Taqwa Jl. Karya Barat, Wijaya Kusuma, Grogol Petamburan, Jakarta Barat, dengan meminjam 3 ruang kelas.

Adapun latihan di dalam bimbingan belajar untuk kelas 1-3 dan kelas 4-6, mata pelajaran bahasa Indonesia, anak-anak diberikan kertas isian dengan topik "Ceritaku". Lihat gambar 1.

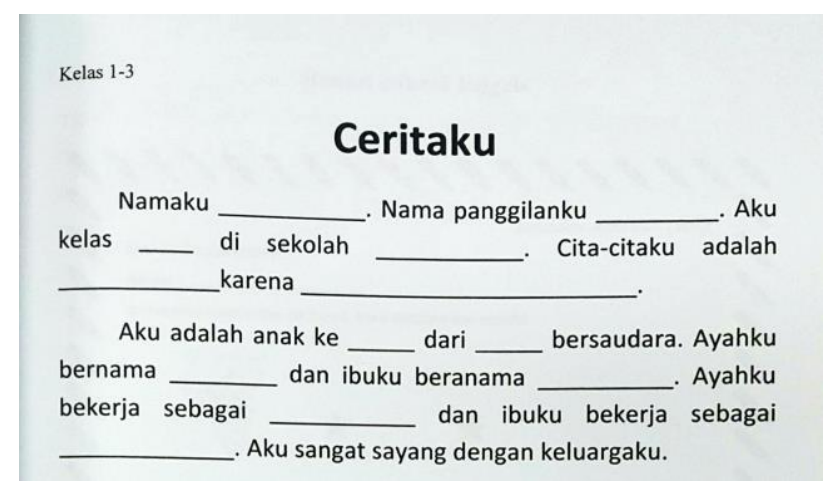

Gambar 1. Ceritaku untuk kelas 4-6

Kertas isian tersebut, nantinya akan diisi nama lengkap, nama panggilan, kelas berapa, sekolah dimana, cita-cita, anak dari berapa bersaudara, nama Ayah, nama Ibu, pekerjaan Ayah, pekerjaan Ibu. Perbedaan isian kelas 1-3 dan 4-6, yaitu pada kertas 
isian kelas 4-6 ditambahkan alasan memilih cita-cita tersebut. Lihat gambar 2.

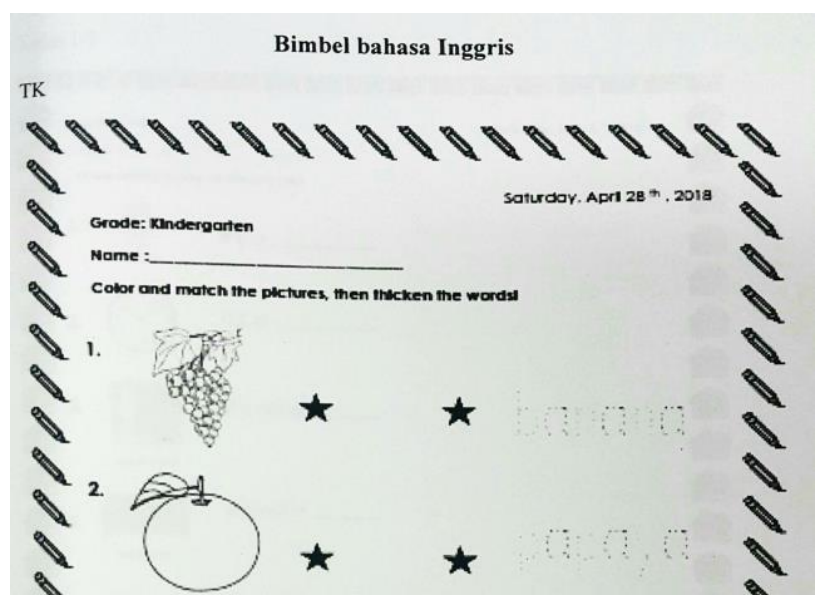

Gambar 2. Ceritaku untuk kelas 4-6

Melalui kegiatan ini, anak-anak diajar untuk mengenali diri bahkan mengekspresikan diri dengan menuliskan biodata dirinya. Biodata adalah pengetahuan dasar yang harus dimiliki oleh setiap orang sebagai pengenalan akan diri.

Latihan dalam bimbingan belajar bahasa Inggris untuk anak TK adalah dengan menyambungkan titik-titik yang merupakan pola berbentuk tulisan bermakna nama buah-buahan. Pada kertas isian tersebut tercantum gambar buah-

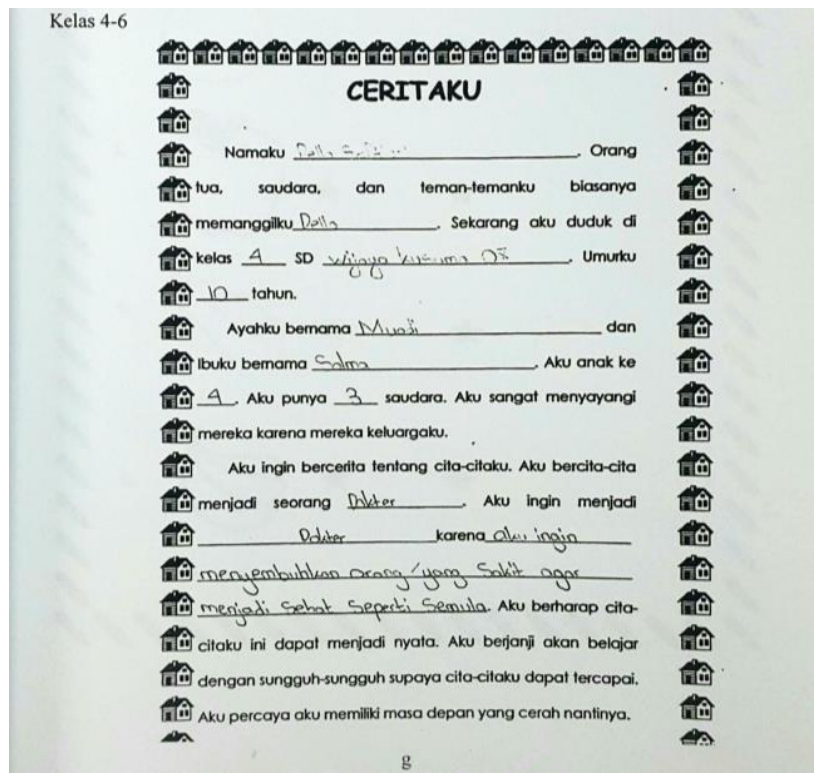

buahan dan disamping kanannya terdapat titik-titik dengan pola nama buah dalam bahasa Inggris.

Gambar 3. Mengenali buah-buahan (TK)

Tujuan dari pembelajaran ini adalah anak dapat mengenali buah-buahan dengan melihat gambar, dan juga menuliskannya nama buah-buahan tersebut dengan menyambungan titik-titiknya sehingga membentuk kata yang bermakna nama buahnya. Lihat gambar 3.

Latihan belajar dalam bimbingan belajar bahasa Inggris untuk anak kelas 1-3 adalah anak-anak diberikan kertas isian yang berisi gambar perabotan yang biasanya ada di rumah seperti kipas angina, jam dinding, televisi, kursi tamu, sapu, lemari, keset, dan ember. Latihan pada kertas isian tersebut, anak diminta untuk mengenali apakah gambar perabotan tersebut namanya sesuai atau tidak. Maksud dan tujuan dari latihan tersebut adalah anak-anak belajar untuk mengenali perabotan yang ada di rumahnya, sehingga dapat memperkaya kosakatanya dalam bahasa Inggris. Lihat gambar 4.

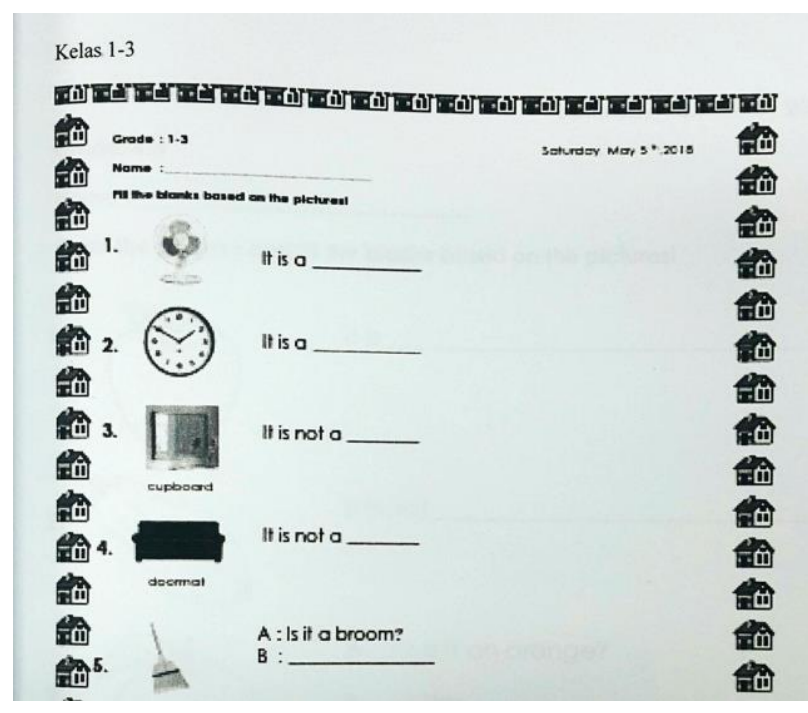

Gambar 4. Belajar bahasa Inggris (kelas 1-3)

Latihan belajar dalam bimbingan belajar bahasa Inggris untuk anak kelas 4-6 adalah anak-anak diberikan kertas yang bergambar buah-buahan. Kemuadian anak diminta untuk mewarnai gambar

$$
\text { Pendidikan }
$$


tersebut sesuai dengan warna buah yang mereka kenali. Misalnya buah anggur, biasanya berwarna ungu, maka anak akan mewarnainya dengan warna

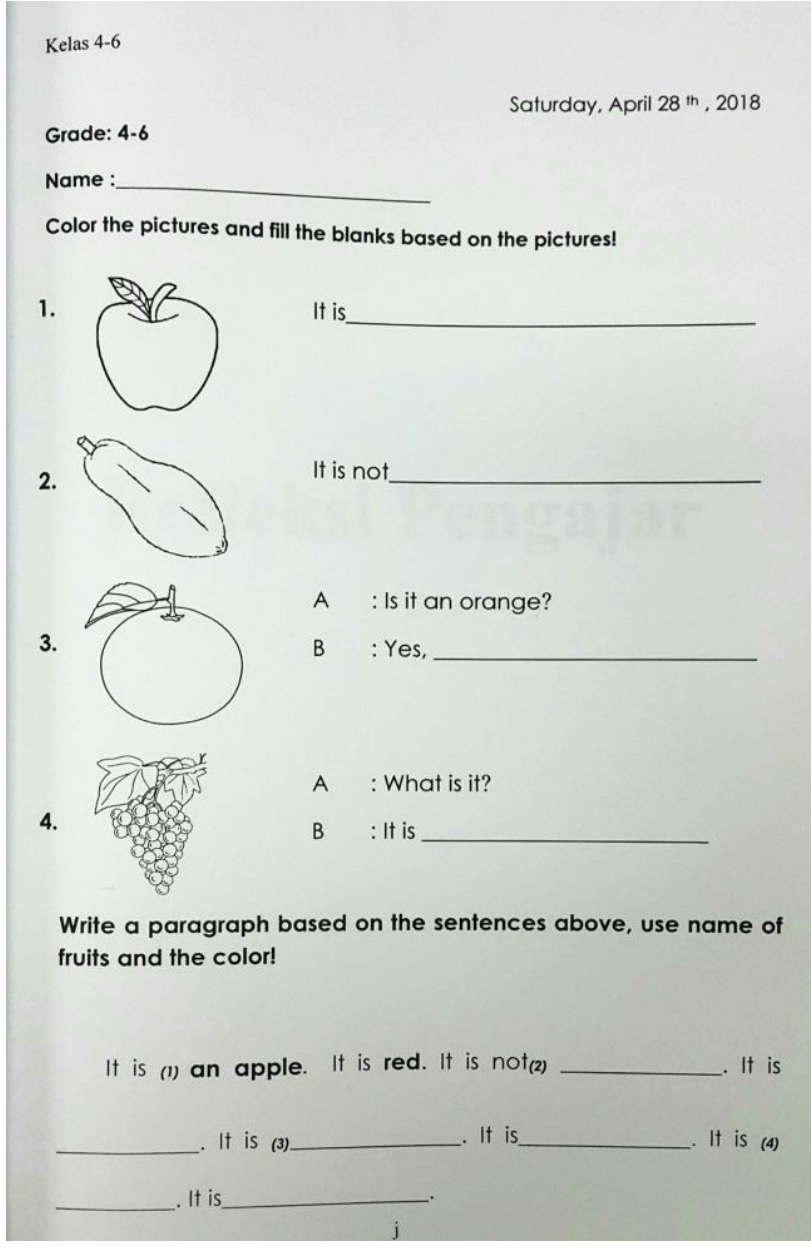

ungu, setelah itu anak diminta untuk mengisi isian di sebelah kanan gambar mengenai nama buah dalam bahasa Inggris. Maksud dan tujuan dari latihan ini adalah mengenali buah-buahan dalam bahasa Inggris beserta warna buahnya. Lihat gambar 4 .

Gambar 5. Belajar bahasa Inggris (kelas 4-6)

\section{Hasil Kegiatan Bimbingan Belajar}

Dalam kegiatan bimbingan belajar ini, siswa dan orang tua siswa memiliki antuasiasme yang sangat tinggi. Rata-rata orang tua siswa termotivasi mengikuti kegiatan ini untuk meningkatkan kecerdasan anak di bidang bahasa dan juga agar anak dapat bersosialisasi dengan lingkungannya. Hal ini dapat dilihat dari hasil evaluasi orang tua siswa yang menyebutkan bahwa alasan mereka mengikut sertakan anak mereka dalam bimbingan belajar ini adalah agar anak lebih cerdas dan mempunyai banyak teman.

Sedangkan dari siswa sendiri, tertarik dalam mengikuti kegiatan ini karena siswa merasa mendapatkan banyak teman baru yang sebelumnya tidak mereka kenal. Antusiasme siswa dalam mengikuti bimbingan belajar ini dapat dilihat dari daftar hadir yang konsisten dari minggu pertama pertemuan hingga minggu terakhir. Hanya saja ada beberapa siswa yang tidak hadir.

Dari setiap materi yang disampaikan dan hasil kegiatan, dapat dilihat bahwa siswa memiliki potensi yang baik dalam berbahasa. Anak menjadi lebih aktif membaca, menulis, dan menghitung dalam Bahasa Indonesia.

\section{Hasil Kegiatan Penyuluhan Orang Tua}

Peserta penyuluhan orang tua ini tersediri dari 15 orang tua. Adapun kuisioner yang dibagikan setelah penyuluhan orang tua. Dalam kuisioner tersbut terdapat 10 pertanyaan yang berhubungan dengan pelaksanaan kegiatan penyuluhan orang tua tersebut.

Berikut adalah analisis dan hasil dari kuisioner tersebut: Pada butir 1) berisi "Apakah Bapak/Ibu berpikir bahwa penyuluhan seperti ini akan membantu Bapak/Ibu untuk mendidik anak/cucu di rumah dengan lebih baik?". Semua peserta menjawab ya, dan ini berarti $100 \%$ menjawab Ya. Dari hasil tersebut dapat dianalisis bahwa semua peserta orang tua merasa penyuluhan ini sangat membantu mereka khsususnya dalam mendidik anak-anaknya di rumah.

Pada butir ke 2) berisi “Apakah Bapak/Ibu bersedia datang lagi jika ada undangan penyuluhan seperti ini?". 100\% menjawab Ya. Dari hasil tersebut maka dapat disimpulkan bahwa semua peserta yaitu orang tua, merasa antusias bahkan ingin terus belajar khususnya dalam mendidik anak-anaknya. Mereka sangat tertarik bahkan bersedia untuk ikut lagi jika ada penyuluhan mengenai peranan orang tua dalam mendidik anak.

Pada butir ke 3) berisi "Apa yang membuat Bapak/Ibu tertarik untuk datang ke penyuluhan ini?". $6.67 \%$ (1 orang) menjawab karena konsumsinya, $6.67 \%$ (1 orang) menjawab karena hadiah kuisnya, dan $86.67 \%$ (13 orang) menjawab karena isi penyuluhannya. Hal ini dapat disimpulkan bahwa

$$
\text { Pendidikan }
$$


orang tua sangat tertarik bahkan belajar banyak melalui informasi dalam penyuluhan orang tua tersebut.

Pada butir ke 4) berisi "Apakah Bapak/Ibu menikmati acara menyanyi bersama dan kuis?". $100 \%$ menjawab Ya. Dapat disimpulkan bahwa orang tua yang hadir sangat menikmati bahkan senang dengan acaranya yang berisi lagu dan permainan atau kuis. Jadi acara ini tidak kaku yang yang berisi materi saja melainkan diselingi dengan interaktif berupa menyanyi dan permainan.

Pada butir ke 5) berisi "Apakah Bapak/Ibu menyukai konsumsi yang diberikan?". 100\% menjawab Ya. Dapat disimpulkan bahwa orang tua menikmati suguhan berupa makanan. Dalam hal ini selain dibekali berupa materi yang akan menambah pengetahuan orang tua, namun panitia PKM juga menyediakan konsumsi agar kebutuhan jasmani orang tua selama mengikuti sesi penyuluhan juga tersepnuhi.

Pada butir ke 6) berisi “Apakah Bapak/Ibu paham dengan materi yang dijelaskan oleh pembicara?". $100 \%$ peserta menjawab Ya. Hal ini dapat disimpulkan bahwa materi penyuluhan orang tua tersebut dapat dipahami orang tua. Jika materi tidak mudah atau bahkan sulit dipahami, maka siasia waktu bahkan dana yang sudah dikeluarkan untuk kegiatan ini, dan terlebih lagi tidak tercapainya tujuan utama yaitu pentingnya orang tua menyadari perannya sebagai pendidik utama bagi anakanaknya.

Pada butir ke 7) berisi "Apakah jam pelaksanaan kegiatan ini sesuai dengan waktu luang Bapak/Ibu?". 100\% menjawab Ya. Dapat disimpulkan bahwa kegiatan ini tidak mengganggu rutinitas dari orang tua. Kegiatan ini dipilih pada hari Sabtu 10 Februari 2018, dengan tujuan orang tua dapat mengikuti kegiatan ini bersamaan dengan liburnnya sekolah di hari Sabtu. Dengan banyaknya orang tua mengikuti kegiatan ini maka diharapkan orang tua menyadari perannya sebagai pendidik utama dalam kehidupan anak-anaknya, dan tentunya hal ini akan sangat mempengaruhi kehidaupan anakanaknya, dan lebih luas lagi akan mempengaruhi masyarakat.

Pada butir ke 8) berisi "Apakah suasana penyuluhan ini membuat Bapak/Ibu dapat belajar dengan baik?". 100\% menjawab Ya. Dapat disimpulkan bahwa kegiatan ini berlangsung dengan sangat kondusif sehingga orang tua dapat menyerap materi dengan baik.

Pada butir ke 9) dan 10) bukan soal berbentuk pilihan ganda atau Ya dan Tidak, seperti soal no $1-8$ ), melainkan berupa pertanyaan esai. Butir ke 9) "Apa sajakan yang Bapak/Ibu dapatkan dari pesan penyuluhan hari ini?". Jawaban dari orang tua cukup beragam. Ada yang menjawab mendapatkan pengetahuan yang baru. Dapat menyanyi dan belajar berkomunikasi dengan pasangan dan anak. Melalui penyuluhan ini belajar banyak dan belajar bersabar sebagai orang tua. Jadi mengerti bagaiaman harus memerankan menjadi orang tua. Belajar mencintai anak-anak sebagai anugerah dari Tuhan dan mengenai masalah anak seperti bully. Belajar lebih mengasihi pasangan dan anak-anak. Belajar banyak mengenai mengatasi masalah anak-anak dan masalah dengan pasangan. Semua jawaban orang tua tidak ada yang negative. Semua positif bahwa mereka belajar banyak khususnya bagaimana seharusnya menjadi orang tua sebagai pendidik utama di dalam kehidupan anakanaknya, dan tentunya orang tua (suami dan istri) harus dapat bekerja sama dalam mendidik anakanaknya.

Butir ke 10) “Adakah masukan/ keluhan/ pertanyaan/ komentar lain? Silahkan tulis do bawah ini!". 100\% menjawab ingin kegiatan ini diadakan lagi karena sangat membantu mereka menjadi orang tua. Jika melihat dari respon orang tua yang snagat auntusias maka ini menjelaskan bahwa penting sekali agar ada kelanjutan dari kegiatan ini. Menjadi orang tua bukanlah pilihan, melainkan panggilan yang Tuhan percayakan khususnya melestarikan bumi ini melalui mendidik anak-anak yang Tuhan karuniakan. Jika orang tua menjalankan perannya sebagai pendidik utama dnegan baik, maka generasi berikutnya akan melanjutkan didikan dari orang tua kepada generasi berikutnya lagi, dengan begitu pengaruhnya sangat besar sekali, bahkan berkelanjutan. Jangan pernah menyepelekan peran orang tua sebagai pendidik di rumah, karena pengarusnya sangat besar, dan lintas generasi.

\section{KESIMPULAN}

Berdasarkan hasil kegiatan bimbingan belajar Bahasa Indonesia dan Bahasa Inggris yaitu menulis, membaca, dan berbicara, dapat disimpulkan 
bahwa kegiatan ini merupakan suatu kegiatan yang sangat bermanfaat bagi anak-anak di daerah Jln. Karya Barat, Wijaya Kusuma, Grogol, Petamburan, Jakarta. Kegiatan ini dapat menjadi pendukung bagi anak untuk semakin meningkatkan kemampuan mereka dalam berbahasa Indonesia dan berbahasa Inggris. Anak-anak yang dilayani juga menunjukkan hasil yang baik dalam mengekspresikan diri mereka baik melalui evaluasi lisan maupun tulisan.

Orang tua juga merasa antusias dan terbuka untuk berbagi pengalaman mendidik anak-anaknya pada acara penyuluhan orang tua di awal pertemuan. Namun, ketika sesi konseling diadakan secara pribadi, orang tua masih malu dan canggung untuk bisa berbicara dengan konselor.

\section{UCAPAN TERIMAKASIH (Bila ada)}

Kegiatan PKM Bimbingan Belajar dan Penyuluhan Orang Tua di Jakarta Barat dapat terlaksana berkat kerjasama dengam SMP Taqwa, dan juga mahasiswa Pendidikan Guru Sekolah Dasar (PGSD) Fakultas Ilmu Pendidikan Universitas Pelita Harapan, dan juga LPPM UPH. Oleh karena itu, dalam kesempatan ini panitia PKM Bimbingan Belajar dan Penyuluhan orang tua mengucapkan terima kasih atas bantuan dan kerjasamanya.

\section{REFERENSI}

Bestiani, Desi., dkk. (2015). Peningkatan Kerjasama Dengan Teman Melalui Permainan Pipa Bocor di TK Negeri 01 Ketapang. Jurnal Pendidikan dan Pembelajaran Khatulistiwa. Vol. 4.

Fitri A., dkk. (2016). Peran Orang Tua Dalam Penanaman Disiplin Pada Anak Usia Prasekolah Melalui Pembiasaan Di Kelurahan Cihaurgeulis Bandung. Jurnal Pendidikan Kesejahteraan Keluarga. Vol. 2.

Guntur, dkk. (2018). Peran Orang Tua Dalam Menanamkan Sikap Disiplin Anak Di Desa Kalimporo Kecamatan Bangkala Kabupaten Jeneponto. Jurnal Tomalebbi. Vol. 5.

Khairini, dkk. (2018). Peran, Fungsi, dan Kedudukan Bahasa Dalam Kehidupan Sehari-hari. Repository Unja.
Megawati, Asriati, dan Rustiyarso. (2017). Peranan Orang Tua Dalam Pendidikan Anak Pada Keluarga Nelayan. Jurnal Pendidikan dan Pembelajaran.

Mursi. 2005. Pendidikan Anak Usia Dini. Jakarta: Tri Aksara.

Nurfadila, Putri (2012). Pentingnya Pembelajaran Bahasa Indonesia Bagi Anak Usia Dini. Jurnal Ilmiah Academia

Rosita, Ita. \& Leonard. (2013). Meningkatkan Kerja Sama Siswa Melalui Pembelajaran Kooperatif Think Pair Share. Jurnal Ilmiah Pendidikan MIPA. Vol. 3.

Sabri, Sakinah Nur (2012). Pentingnya Bahasa Indonesia Bagi Rakyat Indonesia. Jurnal Ilmiah Academia

Santrock, John W. (2007). Psikologi Pendidikan. McGraw-Hill Company, Inc.

Suprapto, Resy. (2014). Pembentukan Disiplin Anak Sekolah Dasar Oleh Ibu Pekerja. Journal Universitas Airlangga. Vol. 3.

Triyanti, Enda. \& Saparahayuningsih, Sri. (2016). Meningkatkan Kemampuan Bekerja Sama Melalui Bermain Simbolik. Jurnal Ilmiah Potensia. Vol.1 (1). 28-35.

Vygotsky, L.S. (1962). Thought and Language. Cambridge, MA: MIT Press. 